\title{
The motive for the action of online gambling as an additional livelihood during social restrictions due to the Covid-19 pandemic
}

\author{
Motif aksi perjudian online sebagai mata pencaharian tambahan selama \\ pembatasan sosial akibat pandemi Covid-19
}

\author{
Yayi Putri Dwihayuni ${ }^{\bowtie}$ \& Agus Machfudz Fauzi \\ Department of Sociology, Faculty of Social Science and Law, State University of Surabaya \\ Surabaya, 60231, East Java, Indonesia \\ E-mail of corresponding author: yayi.20085@mhs.unesa.ac.id
}

\begin{abstract}
Gambling is one of the sub-cultural deviations that have mushroomed in society. Gambling has so far been prohibited by law, but during the difficult times of the pandemic and the implementation of social restrictions in Nganjuk Regency, gambling has become a classic excuse in the midst of the current difficult economy. However, during the social restrictions gambling was mostly done online (via electronic media). This study aims to research and find the background of why many people like to play online gambling. The research method was qualitative. Primary data were obtained through observation and in-depth interviews. This study finds factors that influence the prevalence of gambling during social restrictions, both internal and external factors. This study also finds that online gambling has many types such as lottery gambling, dice, games using cash as the dowry for bets. On the other hand, online gambling is done as entertainment or a hobby. This study concludes that the Covid-19 pandemic causes social problems so that online gambling is used as an additional livelihood and as a hobby by the people in Nganjuk Regency.
\end{abstract}

Keywords: additional livelihood; covid-19 pandemic; social restrictions; online gambling

\begin{abstract}
Abstrak
Judi merupakan salah satu penyimpangan sub budaya yang menjamur di masyarakat. Perjudian selama ini dilarang oleh undang-undang, namun di masa sulit pandemi dan penerapan pembatasan sosial di Kabupaten Nganjuk, perjudian menjadi alasan klasik di tengah sulitnya perekonomian saat ini. Namun pada masa pembatasan sosial perjudian lebih banyak dilakukan secara online (melalui media elektronik). Studi ini bertujuan untuk meneliti dan menemukan latar belakang mengapa banyak orang yang suka bermain judi online. Metode dalam penelitian ini adalah kualitatif. Data primer diperoleh melalui observasi dan wawancara mendalam Penelitian ini menemukan faktor-faktor yang mempengaruhi prevalensi perjudian selama pembatasan sosial, baik faktor internal maupun eksternal. Studi ini juga menemukan bahwa judi online memiliki banyak jenis seperti judi togel, dadu, permainan yang menggunakan uang tunai sebagai mahar taruhan. Di sisi lain, judi online dilakukan sebagai hiburan atau hobi. Studi ini menyimpulkan bahwa pandemi Covid-19 menyebabkan terjadinya masalah sosial sehingga judi online dijadikan sebagai mata pencaharian tambahan dan sebagai hobi oleh masyarakat di Kabupaten Nganjuk.
\end{abstract}

Kata Kunci: mata pencaharian tambahan; pandemi covid-19; pembatasan sosial; perjudian online

\section{Introduction}

Reporting from kompas.com news on July 1,2021, there were 253,826 active cases of the coronavirus in Indonesia. The number of victims exposed to the coronavirus has led to the emergence of new regulations set by the government to break the ropes of the spread of Covid-19 in Indonesia, namely by implementing $3 \mathrm{M}$ (washing hands, wearing masks, and maintaining distance). These $3 \mathrm{M}$ regulations are coercive and must be enforced, resulting in large-scale layoffs and social restrictions, and a reduction in activities in various areas. This causes people to have to stay at home and do work at home in a digital or virtual way by taking advantage of the sophistication of world globalization that can be enjoyed by all people (El-Dairi \& House 2019). In the current era of globalization, it causes many changes that occur in several aspects such as technology, culture, and attitudes or lifestyles. Globalization itself covers 
the breadth and is not limited, making it easier for humans to do and carry out activities (Savira 2015, Septanto 2019). Increasingly sophisticated technology causes many people to take advantage of existing facilities such as the internet. The internet and technology that supports, it makes a person more flexible in accessing the outside world without limits (Håkansson 2020). Changes that continue to occur will result in changes in behavior, attitudes, and new habits in society. Technological advances themselves also have negative and positive impacts on society. The positive impact is that it makes it easier for people to find news, add insight, and provide information. While the negative impacts such as crime in cyberspace or cybercrime, if it is not wise in its use (Nindito 2010).

Crime is a social problem that exists in a society that is very difficult to eradicate. Crime at this time is not only like stealing on the streets or cheating on the street but is more modern by using technology and supported by the internet (Wood \& Williams 2007). With these two things, crime will be easier to carry out everywhere and more efficient in keeping the perpetrator's personal data secret. This is used by criminals because the internet is an alternative to share information, news, and knowledge so that it causes the wider community to establish relationships. An example of a popular crime in cyberspace is online gambling (Price 2020).

The development of information technology has an impact on revolutionizing conventional forms of crime to become more modern. The type of activity may be the same, but with different media, namely the internet, a crime will be more difficult to investigate, process, and prosecute. Crimes that are often related to the internet include gambling carried out via the internet (internet gambling), which is no longer just a conventional crime, but also a crime that can be committed through the sophistication of information and communication technology in this case through the misuse of internet media. Online gambling has been prohibited by law and has criminal acts for the perpetrators as stated in Article 303 paragraph (1) of the Criminal Code and for online gambling is regulated in Article 27 paragraph (2) of Law Number 11 of 2008 concerning Information and Electronic Transactions ("Law No. ITE") jo. Article 45 paragraph (2) of Law Number 19 of 2016 concerning Amendments to Law Number 11 of 2008 concerning Information and Electronic Transactions ("Law 19/2016"). Online gambling is done virtually which in the past if gambling was usually done face to face (Face to face) but in advances in technology. Online gambling is done using smartphones, laptops, or other virtual devices without having to meet first (Lubis \& Syafrizal 2013). Gambling itself has many types such as dice gambling, poker, and lottery (Gunawan 2020).

Online gambling has become commonplace for those who are good at accessing the online world. Many people think that this is a normal thing to have fun playing games. However, in reality, gambling itself has been prohibited by Indonesian legislation (Sugeng 2006). However, this does not break the spirit of the perpetrators themselves in playing online gambling. According to Johansson et al. (2009), online gambling itself is in great demand by players because it is considered safer when playing because they don't have to hide to play the game. So online gambling is an alternative for players to continue to channel their pleasure to gamble.

Online gambling is actually very detrimental because if you lose a bet it will cause other crimes to pay for the gambling bet, it can even cause a loss to yourself from the economic and psychological aspects of the perpetrator himself by winning the bet. However, if you miss the game and lose, it will have a tremendous impact on the perpetrator. Psychologically perpetrators will usually experience pressure, anxiety, and emotions that can harm themselves or those around the perpetrator. So online gambling can make the perpetrators psychologically shaken (Zurohman et al. 2016).

In Nganjuk Regency, East Java, there are already many people playing online gambling. Online gambling is done by teenagers who are looking for extra money for snacks. The perpetrators of online gambling are driven by several motives, such as an invitation from a friend, or indeed seeking profit for free. This habit is used as an alternative way for them to gain profits. These advantages make gamblers more enthusiastic about playing online gambling. With online playing capital, they will get a lot of 
instant profits without having to work hard to make them deeper in playing online gambling so that it becomes a habit to look for additional income in the middle of social restrictions at this time. However, sometimes gambling does not always win a lot from the loser and has to sell some items such as laptops or smartphones.

From the motives circulating, this study is interested in examining this problem and finding out the causes and effects of the risks of playing gambling. This gambling game is in great demand in various walks of life, not only by low-income people but gambling is also often done by people with the uppermiddle economy. Therefore, this study aims to research and find the background of why many people like to play online gambling even though gambling itself has fatal consequences for the economy and psychology of the perpetrators.

\section{Research Method}

This study is based on the development of the theory of phenomenology-Alferd Schutz to study people's motives for action. People do things based on the because of motive and in order to motive to make it the basis for the cause and purpose of action. The location selection was carried out in Nganjuk Regency because there are currently rampant online gambling acts that are considered as irregularities. Primary data was collected through location observations and in-depth interviews with 8 Nganjuk resident informants who did online gambling. This subject is the right informant to describe the research problem while secondary data is obtained from various literature relevant to the topic being studied.

Based on the previous title and background, this research uses qualitative methods because qualitative methods are methods that focus on observation or in-depth observations (Supraja 2015). This qualitative method can describe the phenomenon broadly and thus help to understand the substance of online gambling events. This study was conducted to produce an accurate result based on observations and interviews in the field. The data is selected by selecting based on the answers that many informants answered when interviewed. After that, the data will be searched for references from various journals so that the results are accurate and in accordance with the facts and analyzed using previous studies.

\section{Results and Discussion}

In July 2021, Indonesia experienced a panic that made the public feel restless because of the very high spike in the number of active cases of the coronavirus, which prompted the government to implement several new rules to break the ropes of the spread of Covid-19, starting from the application of $3 \mathrm{M}$ (wearing masks, washing hands, and keep the distance). The government also implemented PSBB (large-scale social restrictions), and PPKM (restrictions on enforcement of community activities) in various regions. This causes a reduction in community activities and makes people more active at home doing all activities, as well as the many layoffs that cause people to think about staying afloat and having enough in the difficult times of the current pandemic.

In the era of globalization, making life more advanced and easy to explore without having to come or meet, online gambling can be done through electronic media and supported by the internet. Internet is a communication network that connects one device to another quickly. With the internet and supported by the development of science and technology in the world, it can affect people's behavior, interactions, and lifestyles (González-Cabrera et al. 2020). Technological developments make many people flock to use it to explore the outside world. However, there are certain elements that do not use the internet wisely, giving rise to crime in cyberspace or known as cybercrime, one of which is online gambling (Price 2020).

The influence of technological developments that is not accompanied by a wise way of using it will backfire for its users. The online gambling players initially only played gambling as a means to entertain themselves or just play around but these activities would cause a sense of addiction if it is done 
continuously (Manalu 2019). Many gambling players who play gambling games start from frequently accessing the internet world such as playing games and others to the intensity of a longer time compared to other more useful activities. There are two basic things that must be observed to determine the intensity of one's internet use, namely the frequency of the internet that is often used and the length of time it is used every time internet users access the internet. Three categories of internet users based on internet intensity, namely: 1) heavy users (more than 40 hours per month) 2) medium users (between 10 to 40 hours per month) 3) light users (less than 10 hours per month) (Drosatos et al. 2018).

\section{The reason for the rise of online gambling during the pandemic}

Gambling is an action that earns profit for free (Sanjaya 2018). By choosing one of the other options and having the opportunity to win, the player will get a predetermined advantage in his own game, usually, it has been discussed in advance by the gambling player to determine how many nominal numbers will be bet and what nominal numbers will be obtained if win (Auer et al. 2020). Gambling has several variations including number bets, dice, soccer, and poker which are done through electronic media. On the other hand, many are found on websites or internet pages that advertise gambling as an instant way to get money in this pandemic situation so that online gambling is used as an alternative for those who like to play gambling without having to hide to play the game. This adds to the bold impression of online gambling players.

Online gambling is in great demand because of the lure of getting the money instantly with a fantastic amount. Seeing the many gambling platforms that have sprung up as persuasion has led to increasing the stability of online players to play gambling in the midst of this pandemic situation. Online gambling is also widely done to fill spare time because everything is online so work can be done simultaneously with playing other activities (Gainsbury et al. 2020). Many teenagers or adults play gambling because they are experimenting or curious about the game because of the many advertisements circulating on the internet and various social media platforms. These advertisements will persuade or compel them to play online gambling with the lure to get money instantly and quickly just by playing games only (Quoilin et al. 2020). The persuasion of the advertisement will affect the public if the public cannot digest and be careful so that it affects the people's actions to carry out the gambling game.

"Gambling is carried out at various levels of society, age, and gender. Not only adults but teenagers are familiar with and play gambling nowadays", said DON, who was one of the interviewees during an in-depth interview at the location. Technological advances make many innovations emerge from the internet world so that many new things can be accessed and explored so that people who are less wise in accessing the internet can use the internet to be used as an income field instantly.

Online gambling itself is an alternative that is in great demand by the public in the current pandemic situation and the implementation of social restrictions. Several factors cause why online gambling is rife in the community, the first is the economic and social aspects. Often someone gambles online because of the lure of getting multiple benefits from the capital spent. This is one of the short thoughts that gambling players often encounter because they want to improve their standard of living instantly. Second, situational factors. These factors can be due to the influence of friends and the surrounding environment where someone who often interacts with us will automatically affect individual behavior. The third, the learning factor. Because the lure of free profits causes many people to learn to play gambling to understand every tactic and trick in playing the game. Because the profit is quite big, it will have a big enough effect on gambling players. Individuals will tend to strengthen or repeat the game until it becomes a habit. This is explained in reinforcement theory because where a person can make his choices and make decisions for his life by accepting the consequences that will occur (Fitriani et al. 2014). Fourth, the probability factor. Because of the perception that gambling will continue to win if they have skills, this makes gamblers take advantage of opportunities to continue to win games and repeat them continuously to get profits of up to tens of millions of rupiah. 


\section{Motives for online gambling in Nganjuk Regency}

In Nganjuk, East Java, online gambling is rampant in society and does not look at a person's age or gender. Gambling in Nganjuk Regency became an alternative to get extra money when social restrictions were implemented in Nganjuk in January 2021. Many of them play because of a friend's invitation to form a reliable player. "Previously, gambling has often been done by some people who like to play online games, these people play poker card games with cash bets as the gambling dowry" (The informant DEW).

This online gambling practice has mushroomed among the Nganjuk community. This happens because of the unstable condition of society from various aspects such as economy, morals, and legal awareness, which lacks understanding of criminal law which blinds gamblers to not care about the law and continue to do gambling which has become a habit done. So that it can be said as a routine activity that must be fulfilled every day if it is not fulfilled it will cause a feeling of anxiety that continues to haunt.

"I'm not too afraid to play this game, especially online gambling, identity can be disguised and there is no need to meet face-to-face when playing. Moreover, online gambling has become commonplace among the community as gambling has become a common game to play. In addition to fun and hobbies, gambling also makes us suddenly rich as long as we know the tricks and tactics to be able to read the odds of winning. It spurs us to keep playing until we get a lot of profit. In this day and age, it has also been found on various platforms on the internet so that this game has a wider reach and is no longer an unusual game" (The informant AGA)

The continuous social restrictions period in Nganjuk is one of the causes of the rise of online gambling in the community. The biggest motive behind this online gambling is money. The difficulty of getting money during the pandemic causes someone to try their luck and look for extras by playing online gambling. Lack of knowledge in the internet world causes people's freedom to play on the internet without thinking about the impact and applicable legal by trying online gambling to get instant profits (Fitriani et al. 2014). However, many people do not pay attention to these regulations because they are based on the desire for the benefits obtained from playing gambling. The results of these trials will make the gambler addicted so as to make online gambling a livelihood whose profits depend on it to increase the gambler's income.

Because gambling is considered normal in some communities, this causes gambling site owner to promote their gambling platforms to several game advertisements, websites, and other social media platforms. These advertisements will persuade internet users to play online gambling with the lure of getting money instantly and quickly just by playing games. These advertisements contain elements of adult content to increase user attractiveness. This is a surefire way for online gambling platform owners to promote their gambling platforms by using beautiful and sexy models as their brand ambassadors.

Not only from the internet factor but many of the gamblers are affected by the surrounding environment such as an invitation from a friend. Social interaction is very influential in a person's actions. Someone will understand something faster if they interact face to face (Susanti 2021). For example, there is someone who is a friend and he influences other friends to gamble online with the lure of getting extra money to eat and play. If someone who is invited is willing and does not filter or think about the future impact so that he agrees to his friend's invitation, then they will collaborate and work together to win in gambling. This causes them to become perpetrators of social deviance crimes called organized crimes, in which crimes of social deviance are carried out in a planned and joint manner with the aim of making money or power by opposing the law. This is against the law and there will be a fatal crime if caught by the authorities (Hasanah 2008).

Gambling games recognize the terms win and lose, those who play gambling if they win will get big profits from the agreed bet results (Hing et al. 2015). But if he loses, he will give up his money to be taken by someone else. In addition, playing gambling must have a sensation that will be addictive. 
Addiction is the feeling of wanting to repeat again until the feeling will arise continuously and will become stressed or restless if it is not fulfilled (Patrick 1988). It happens because if someone wins one gamble it will create a sense of addiction to gamble again in order to get more profits. This makes gamblers feel challenged when playing and hone their skills so that if they win, they will feel proud of themselves. This sense of pride will influence a gambler to continue gambling because of a sense of self-satisfaction (Kim et al. 2014).

During this pandemic and social restrictions in the Nganjuk district, it is very difficult to make money because of the large number of layoffs that harm the workers causing economic needs to be unfulfilled, so they looking for other alternatives. In the midst of the current difficulty of the pandemic, online gambling is used as an alternative for those who are desperate with the situation, in order to fulfill their needs under the guise of trial and error.

"Times are difficult, it's hard for everyone to work, layoffs and selling evicted, dizzy thinking about the burden of living during the current pandemic situation. Yes, I tried this gamble because of a friend, also while learning to gamble who knows who wins, it's not bad" (The informant AHM)

In Alfred Schutz's view, the act of gambling is in order to motive because the purpose of someone doing online gambling is to improve their standard of living in an instant way and because of the motive of this action is because many people need money to fulfill their needs (Sitompul et al. 2014). However, not only that, but social factors also influence the motive because of the stimulation from the surrounding environment so that it can influence someone to take action. They do online gambling to get a lot of money to be able to meet wants and needs in the future. So that in Alfred Schutz's theory it has been solved the causes and goals of online gamblers play these online gambling games.

\section{Negative impacts of playing online gambling}

Gambling is one of the social pathologies in society that is rife today and is very disturbing. The act of playing gambling is included in the qualification of crime. Online gambling itself will cause damage to the social system in society. Norms that apply in the community and customs are not integrated with behavior and the loss of religious beliefs and moral regulations (Hafifa \& Sugeng 2017). Every action taken by a person must have an impact that can be felt directly whether it is a negative or positive impact. The behavior can be seen by the people around. The perceived impact is the risk they take. The gamblers are aware of these perceived impacts but they prioritize their passions. This action will continue to bring gamblers to continue playing it non-stop so that they become anti-social people and don't care about what happens to themselves and those around them. Anti-social is a term to describe a personality disorder that occurs deviation of normal behavior (Challet-Bouju et al. 2020).

Online gambling is a cybercrime that is often encountered. In the difficulty of this pandemic period and the implementation of social restrictions caused many people to lose their jobs and businesses and look for an escape to get instant money from online gambling results instead of being able to increase their income and better living (Granero et al. 2020). Gambling is a deliberate bet, which is risking one value or something that is considered valuable based on an agreement to obtain an uncertain victory. In this game, only one person will win and get a prize. The losing opponent must give up their betting property taken by the winner, this is very detrimental and can lead to other crimes such as stealing due to paying for betting money playing gambling.

When deciding to play gambling, these gamblers must accept the consequences. They choose to play gambling so they have to accept the risks and impacts. There are many impacts but they don't pay attention to it because they are addicted to playing gambling (Macdonald et al. 2001). Addiction causes a person to have to continuously fulfill his desires so that unwanted things do not happen such as stress and depression (Slutske 2006). The desire of gambling is powerful enough to hypnotize someone to perform actions that are a temporary pleasure so that those who cannot control their passions will fall into misery. 
Gambling games are played by those who seek temporary happiness. What is meant by momentary happiness is happy when they win a gambling game but they will play again to get a bigger profit (greedy). As a result, there are several causes and effects felt by acute gamblers such as 1) encouraging them to embezzle money to play gambling; 2) the power of thought is reduced, causing humans to tend to take risks without considering the impact (only prioritizing lust); and 3) an unhealthy body condition due to staying up late playing gambling.

"The impact is actually more negative. I also realized that since this online gambling my body has become sick from lack of sleep. I'm so lazy to work. My wife and children are angry because we have no money, and it can affect my children too. There are so many impacts that I actually feel, but I can't help but get addicted" (The informant AHM)

Some of the negative impacts of online gambling include, first, the psychological impact. When playing online gambling, the gambler's psychology will be shaken. Feelings of emotion, ambition, and tension will become one so that they can endanger themselves and others around them because if they get out of control and experience stress, they can hurt themselves and others around them. The second, the biological impact. Biologically, this addiction can impair cognitive function. The third, the physical impact. Physically it can be seen clearly the differences that appear in gamblers, the body will feel achy due to lack of sleep and obesity because every day they just sit and there is no physical activity or even malnutrition because they tend to eat instant food such as instant noodles or non-nutritive food. Fourth, social impact. Usually, people who play online gambling are more apathetic about anything, they spend more time in cyberspace and rarely interact with people around. Fifth, the impact on the nerves of the brain. Those who experience internet addiction, generally have the desire to stop but they can't stop. There are also emotional and memory disorders, so their memory power goes down and their emotions become unstable. The sixth, tucked-away porn sites. When gambling players access online gambling sites or platforms, many pornographic contents are often found in them. This is not just content, but pornographic content is deliberately done to attract the attention of the site's users. Seventh, malware and virus attacks. Service sites or online gambling platforms are vulnerable to containing malware or viruses because sites such as online gambling have such high access that they become a target for digital criminals to spread malware or viruses to site users. This is very dangerous because it not only interferes with the running system, malware can also steal important data, change, and even control the existing system.

\section{Conclusion}

This study concludes that technological advances also have an impact on the weakening of social values that exist in society, such as the emergence of social problems that disturb the community such as gambling. During this pandemic, online gambling is rampant in the community. From these problems, it can be seen that people think that this is a common occurrence as in usual gambling. But on the other hand, there are those who oppose online gambling because it can cause anxiety and have a bad impact on them and those around them. Online gambling can harm anyone so that it will be fatal if they desire to play gambling is not fulfilled.

Gambling is usually done directly (face to face) but in this pandemic situation and the social restrictions in Nganjuk Regency, it is carried out online that utilizes technological advances and is supported by the internet which is easily accessible. Gambling players experience anxiety because with online gambling there is capital that must be provided to be used as collateral that is not necessarily returned so that it causes material losses and tends to be violent towards himself and others around them.

Even though there is already a criminal law that applies to gambling players, it does not make gamblers afraid and deters. Not only criminal law has a negative impact on gamblers' physical and mental health, but this is also very dangerous for gamblers and those around them. Mentally and emotionally the 
gamblers will be more unstable so that it can cause bipolar disorder due to high stress and traumatic experiences by gamblers when playing gambling.

\section{References}

Auer M, Hopfgartner N, \& Griffiths MD (2020) The effects of voluntary deposit limit-setting on longterm online gambling expenditure. Cyberpsychology, Behavior, and Social Networking 23 (2):113-18.

Challet-Bouju G, Grall-Bronnec M, Saillard A, Leboucher J, Donnio Y, Péré M, \& Caillon J (2020) Impact of wagering inducements on the gambling behaviors, cognitions, and emotions of online gamblers: A randomized controlled study. Frontiers in Psychiatry 1-12. https://doi.org/10.3389/ fpsyt.2020.593789.

Drosatos G, Arden-Close E, Bolat E, \& Vuillier L (2018) Gambling behaviour data and modalities of persuasive interaction for enabling responsible online gambling. Technical report Bournemouth University, Poole.

El-Dairi M \& House RJ (2019). Optic nerve hypoplasia. Handbook of Pediatric Retinal OCT and the Eye-Brain Connection 285-87.

Fitriani FA, Samad, \& Khaeruddin K (2014) Penerapan teknik pemberian reinforcement (penguatan) untuk meningkatkan hasil belajar fisika pada peserta didik kelas VIII.A SMP PGRI Bajeng Kabupaten Gowa. Jurnal Pendidikan Fisika Unismuh 2 (3):120887.

Gainsbury SM, Abarbanel B, \& Blaszczynski A (2020) The relationship between in-play betting and gambling problems in an Australian context of prohibited online in-play betting. Frontiers in Psychiatry 1-9. https://dx.doi.org/10.3389\%2Ffpsyt.2020.574884.

González-Cabrera J, Machimbarrena JM, Beranuy M, Pérez-Rodríguez P, Fernández-González L, \& Calvete E (2020) Design and measurement properties of the online gambling disorder questionnaire (OGD-Q) in Spanish adolescents. Journal of Clinical Medicine 9 (1):120.

Granero R, Jimenez-Murcia S, del Pino-Gutierrez A, Mora B, \& Fernandez-Aranda F (2020) Gambling phenotypes in online sports. Frontiers in Psychiatry 1-13. https://doi.org/10.3389/fpsyt.2020.00482.

Gunawan T (2020) Rasionalitas Pembentukan perilaku judi togel (toto gelap) di masyarakat (studi kasus: Desa Sambigede, Kecamatan Sumberpucung, Kabupaten Malang). JSHP : Jurnal Sosial Humaniora Dan Pendidikan 5 (1):81-88.

Hafifa N \& Harianto S (2017) Studi fenomenologi motif melakukan judi togel di Surabaya. Paradigma $5(1): 1-9$.

Håkansson A (2020) Impact of covid-19 on online gambling - a general population survey during the pandemic. Frontiers in Psychology 11 (September):1-8.

Hasanah H (2008) Tindak Pidana perjudian melalui internet (internet gambling) ditinjau dari Undang-Undang Nomor 11 Tahun 2008 Tentang Informasi Dan Transaksi Elektronik. Majalah Ilmiah UNIKOM 8 (2):231-42.

Hing N, Cherney L, Gainsbury SM, Lubman DI, Wood RT, \& Blaszczynski A (2015) Maintaining and losing control during internet gambling: A qualitative study of gamblers' experiences. New Media and Society 17 (7):1075-95.

Johansson A, Grant JE, Kim SW, Odlaug BL, \& Götestam KG (2009) Risk factors for problematic gambling: A critical literature review. Journal of Gambling Studies 25 (1):67-92.

Kim HS, Wohl MJA, Salmon MM, Gupta R, \& Derevensky J (2014) Do social casino gamers migrate to online gambling? An assessment of migration rate and potential predictors. Journal of Gambling Studies 31 (4):1819-31.

Lubis DH \& Syafrizal (2013) Judi online di kalangan mahasiswa kota pekanbaru studi kasus mahasiswa yang berdomisili di Kecamatan Tampan. Thesis, Universitas Riau, Pekanbaru.

Macdonald JF, Turner N, Bartoshuck MR, \& Zangeneh M (2001) Adolescent understanding of the emotional and cognitive aspects of gambling: The development of a prevention strategy. Culture and the Gambling Phenomenon. Proceedings of the 11th Conference of the National Association for Gambling Studies 204-214. 
Manalu HS (2019) Penegakan hukum terhadap pelaku tindak pidana perjudian online. Journal of Education, Humaniora and Social Sciences (JEHSS) 2 (2):428-47.

Nindito S (2013) Fenomenologi Alfred Schutz: Studi tentang konstruksi makna dan realitas dalam ilmu sosial. Jurnal Ilmu Komunikasi 2 (1):79-95.

Patrick CH (1988) Lessons from longitudinal studies. Vital and Health Statistics. Ser. 4: Documents and Committee Reports 53 (25):163-173.

Price A (2020) Online gambling in the midst of covid-19: A nexus of mental health concerns, substance use and financial stress. International Journal of Mental Health and Addiction. https://doi. org/10.1007/s11469-020-00366-1.

Quoilin C, Grandjean J, \& Duque J (2020) Considering motor excitability during action preparation in gambling disorder: A transcranial magnetic stimulation study. Frontiers in Psychiatry 1-13. https://doi.org/10.3389/fpsyt.2020.00639.

Sanjaya FN (2018) Application of law information and electronic transactions in crime investigation of online gambling. Jurnal Daulat Hukum 1 (2):537.

Savira SI (2015) Equalizing quality: The challenge of globalization. Jurnal Psikologi Teori dan Terapan $6(1): 54$.

Septanto A (2019) Perilaku menyimpang masyarakat penjudi merpati di Surabaya. Jurnal Sosiologi Dialektika 14 (2):126-131.

Sitompul MM, Ablisar M, Hamdan M, \& Leviza J (2014) Kebijakan kriminal dalam penanggulangan tindak pidana judi online yang dilakukan Markas Besar Kepolisian Republik Indonesia (Mabes Polri). Usu Law Journal 2 (2):187-200.

Slutske WS (2006) Natural recovery and treatment-seeking in pathological gambling: results of two U.S. national surveys. American Journal of Psychiatry 163 (2):297-302.

Supraja M (2015) Alfred Schutz: Rekonstruksi teori tindakan Max Weber. Jurnal Pemikiran Sosiologi $1(2): 81$.

Susanti R (2021) Judi online dan kontrol sosial masyarakat pedesaan (online gambling and social control of rural communities). ETNOREFLIKA: Jurnal Sosial Dan Budaya 10 (1):86-95.

Wood R \& Williams R (2007) Internet gambling: Past, present and future. Research and Measurement Issues in Gambling Studies 486-502.

Zurohman A, Astuti TMP, \& Sanjoto TB (2016) Dampak fenomena judi online terhadap melemahnya nilai-nilai sosial pada remaja (studi di Campusnet Data Media cabang Sadewa Kota Semarang). Journal of Educational Social Studies 5 (2):156-62. 